Original Paper http://ajol.info/index.php/ijbcs $\quad$ http://indexmedicus.afro.who.int

\title{
Damage mechanisms of pathogenic bacteria in drinking water during chlorine and solar disinfection
}

\author{
Seyram K. SOSSOU ${ }^{1 *}$, Dotse K. GBEDENU ${ }^{1}$, Yacouba KONATE ${ }^{1}$, \\ Boukary SAWADOGO ${ }^{1}$, Yaovi AMEYAPOH ${ }^{2}$, Amadou H. MAIGA ${ }^{1}$ \\ and Naoyuki FUNAMIZU ${ }^{3}$
}

\author{
${ }^{1}$ Laboratory of Water, Sanitation, Ecosystem and Health (LEDES), International Institute for Water and \\ Environmental Engineering (2iE), PO Box 594, 01 Rue de la science, Ouagadougou, Burkina Faso. \\ ${ }^{2}$ Laboratoire de Microbiologie et de Contrôle de Qualité des Denrées Alimentaires, Ecole Supérieure des \\ Techniques Biologiques et Alimentaires, Université de Lomé, B.P. 1515, Boulevard Eyadema, Lomé, Togo. \\ ${ }^{3}$ Department of Environmental Engineering, University of Hokkaido, Kita 13-Nishi 8, Kita-ku, Sapporo, \\ Hokkaido 060-8628, Japan. \\ *Corresponding author, E-mail: seyram.sossou@2ie-edu.org; Tel. +22671923148
}

\begin{abstract}
This study aimed at elucidating the inactivation mechanisms of pathogenic bacteria in drinking water during chlorine and solar disinfection using a simple plating method. The well-known bacterial model Escherichia coli was used as pathogenic bacteria for the experiments. The damage mechanisms of $E$. coli were evaluated by simple plating method on selective, less selective and non-selective media. Results showed that, injured E. coli were detected at different levels during chlorine and solar disinfection. The use of selective media during water quality control showed effectively the destruction of $E$. coli during solar disinfection while the removal of $E$. coli during chlorine disinfection was not ensured. The damage of cell components and/or metabolic functions showed that there is a primary and mainly damage of $E$. coli during chorine and solar disinfection. Chlorination firstly and mainly damaged membrane cell followed by that of enzymatic functions and nucleic acid; while solar disinfection damaged mainly nucleic acid. The use of simple plating method in water quality control is limited by the choice of plating media depending on the disinfectant used. The understanding of the damage mechanisms of pathogenic bacteria cells during disinfection helps improve drinking water quality control and develops more effective disinfection strategies.
\end{abstract}

(C) 2016 International Formulae Group. All rights reserved.

Keywords: Drinking water, pathogenic bacteria, E. coli, damage mechanisms, chlorine disinfection, solar disinfection.

\section{INTRODUCTION}

Over the next decades, water crisis are inevitable and more than one billion people have no access to safe drinking water (WHO and UNICEF, 2014). As a result, millions of people, mostly young children, die every year of water-related diseases, especially in developing countries. The detection of microbial contaminants responsible for these diseases has so far largely improved and 
researchers have found that several waterborne microorganisms including pathogenic bacteria may persist in potable drinking water (Cabral, 2010; Orjiekwe et al., 2014).

Water disinfection has gained importance due to the emergence of waterborne pathogens which are resistant to conventional water treatment technology (Richardson and Postigo, 2012; Wahome et al., 2014). Resistant waterborne pathogens' deposition and dispersion in the environment can substantially reduce the quality of received waters and represent a considerable risk for human health (Hrudey and Charrois, 2012). Among the traditional water disinfection technologies, the chlorination process is the first and foremost disinfection process, and used for 100 years. However, there has been an increasing public concern for over 40 years relating to the formation of disinfection by-products (DBPs) such as trihalomethanes, haloacetic acid, and nitrogenous DBPs (Zogo et al., 2010; Xue et al., 2014). Moreover, some waterborne pathogenic bacteria, ubiquitous in biofilms, are resistant to free chlorine (Ramseier et al., 2011). The most widespread commercial alternatives to the use of chlorine-based oxidants are ozonation and filtration but these technologies also have their limits.

In recent years, UV light was increasingly used as a disinfectant, as it effectively inactivates bacteria and somewhat forming DBPs that are relatively less than that upon chlorination (Shah et al., 2012). Solar irradiation containing UV lights can also be used for disinfection and the inactivation of many waterborne microorganisms including bacteria has already been reported (McGuigan et al., 2012). Water is already treated in many sunny areas by solar disinfection or SODIS; the term SODIS particularly refers to the solar disinfection of drinking water in PET bottles on a small household scale (Mcguigan et al., 2012). The SODIS process relies heavily on the solar UV-A which, as received at sea level, is composed of roughly similar portions of both direct and diffuse electromagnetic irradiations. Given the diffuse nature of the UV-A and the cylindrical shape of the bottles, the use of concentrating systems based on non-imaging optics with low concentrating factor has the potential to enhance SODIS.

The primary focus of most studies provide information on disinfectant doses and contact times (Cho et al., 2010) required to adequately control pathogens as public threat. However, the mechanisms of microbial cells inactivation are relatively not well established compared to a large database of inactivation kinetics, partly because incidences that trigger the cell death or inhibit further growth involve diverse and complex methods (Cho et al., 2010). Generally, the efficacy of water disinfection processes is monitored by measurements of bacteria using traditional plate count techniques. However, inactivation of specific bacteria or bacterial groups does not guarantee an acceptable degree of removal of other waterborne organisms (Rizzo, 2009). In most cases, conventional cultivation covers the minority of bacteria occurring only in a certain habitat. Even bacteria that usually grow on traditional media can lose cultivability after chlorine and solar disinfection and this, despite retaining viability and infectious capacity (Giannakis et al., 2014). These underlining showed that not only water treatment technologies need to be improved, but also water quality control methods.

To fully assess water purification processes, it is important to characterize the injury, lethal and sub-lethal damage caused by disinfection processes and identify the potential for bacterial re-growth (Dunlop, 2011). The damage mechanisms of bacteria cells involved are most commonly explained as the destruction of the organism protein structure and the inhibition of enzymatic activities as well as the nucleic acid and morphological structure (Cho et al., 2010). So far, most research activities focused on the investigation of bacteria damage with complex techniques. There have been a few studies only, in which DNA damage and repair after chlorine and UV exposure were 
estimated using molecular methods based on specific antibodies measurement (Al-Adhami et al., 2007) or the use of polymerase chain reaction (Escheid et al., 2009). Consequently, there is still a lack of simple standard method on the primary pathway of disinfectant interaction with microorganisms.

This study aimed at elucidating the inactivation mechanisms of pathogenic bacteria in drinking water during chlorine and solar disinfection using a simple plating method.

\section{MATERIALS AND METHODS}

Bacteria strains and bacterial suspension preparation

In this study, Escherichia coli was used as pathogenic bacteria model. The bacterial strain used was E. coli ATCC 25922 (a primary indicator of water fecal pollution) which was purchased from the American Type Culture Collection (ATCC, USA). The procedure used for the preparation of bacteria suspension was based on the method of Cho et al. (2006). In brief, a freeze-dried pellet of $E$. coli was first rehydrated aseptically using Tryptic Soy Broth (Difco Co., USA) and grown for overnight at $37{ }^{\circ} \mathrm{C}$. Bacterial cells were then harvested from the broth by repeating centrifugation at $1000 \mathrm{~g}$ for $10 \mathrm{~min}$ at $4{ }^{\circ} \mathrm{C}$ and washing it with $50 \mathrm{ml}$ of phosphate buffered saline (PBS, $150 \mathrm{mmol}^{-1}$ at $\mathrm{pH}$ 7.1). The stock suspension of bacteria was prepared by re-suspending the final pellets in PBS stock solution.

\section{Water and disinfectants used}

This study was carried out using ultrapure water to exclude a possible contribution of any detected compounds, e.g. organic matter or metals in the process and to prove that the disinfection effect only exists due to chlorine concentration or solar UV irradiation. All experiment solutions were prepared using ultrapure water obtained by pure water system (Barnstead Co., USA). All the glassware was cleaned using distilled water and further autoclaved at $121^{\circ} \mathrm{C}$ for 15 minutes.
For chlorine disinfection, chlorine was used. A free chlorine stock solution (approximately $50 \mathrm{mg} . \mathrm{l}^{-1}$ ) was prepared by diluting sodium hypochlorite solution (13\%, Junsei Co., Japan). The concentration was determined by the DPD colorimetric method using a DR/2010 Spectrophotometer (HACH Co., USA). For solar disinfection natural UV lights from sun was used.

\section{Disinfection procedure}

Chorine disinfection was performed in a head-space-free Pyrex piston-type reactor that could hold $50 \mathrm{ml}$ test solution. The experiment was initiated by transferring instantly the concentrated disinfectant stock solution into the reactor containing PBS $(\mathrm{pH}$ 7.1) of bacteria suspension. Chlorine solution previously prepared was added at dose 0.5 mg. $1^{-1}$ for cell suspensions. During experiment, the solution was mixed using a magnetic stir bar placed inside the reactor. As control, the same amount of sample was prepared without chlorine. Samples were taken at different times (0-4 hours) from the sampling outlet of the reactor and collected into sampling bottles without contact with the atmosphere. The residual disinfectants were instantaneously quenched using excess sodium thiosulfate before analysis.

Solar disinfection experiments were conducted in Ouagadougou, the capital city of Burkina Faso. The experiment was carried out in April, in a dry season period, and there was no rainfall during all the experimental period. The experiments were conducted with new, locally purchased smooth-surface 1.5 1 PET bottles. The bottles were exposed to sunlight from 9:00 a.m. to 5:00 p.m. As control the same amount of sample was wrapped with aluminum foil before subjected to sunlight. The mean meteorological data of the experimental day were taken from Burkina Faso's Meteorology Station. Therefore, from 9:00 a.m. to 5:00 p.m., the average daily level of solar radiation was $598.4 \mathrm{~W} . \mathrm{m}^{-2}$; the average relative humidity was $48 \%$ and the ambient temperature was $35^{\circ} \mathrm{C}$. Samples were taken at different intervals time (0-8 hours) during experience and immediately wrapped 
with aluminum foil to keep them in the dark before analysis.

\section{Seeding of $E$. coli}

E. coli was seeded using the spread plate method. One milliliter aliquot of sample was withdrawn from the sample at various reaction times and a 10 -fold serial dilution was performed up to $1 / 100,000$ dilution ratio using PBS. Each diluted suspension $(0.1 \mathrm{ml})$ was spread in duplicate on corresponding agar media plates. The plates were incubated at 37 ${ }^{\circ} \mathrm{C}$ for $24 \mathrm{~h}$. The results are mean data from at least three experiments, with the standard deviations being indicated by error bars.

\section{Media for enumeration damaged $E$. coli}

For evaluating the degree of injury of E. coli, samples were plating onto two types of agar media: m-Endo agar (Difco Co., USA) and mTergitol-7 media (mT7) (Oxoid, USA). According to McFeters (1990) the degree of injury of the bacteria was quantified using the following equation:

$$
\operatorname{Injury}(\%)=\frac{\mathrm{mT} 7-\mathrm{mEndo}}{\mathrm{mT} 7 * 100}
$$

where mT7 and mEndo represent the concentration of injured and non-injured bacteria respectively (measured in $\mathrm{CFU} \mathrm{ml}{ }^{-1}$ ).

\section{Media for estimation damage of $\boldsymbol{E}$. coli}

In order to estimate the damage mechanisms of E. coli, 3 types of agar media were used. This three media are: Tryptic Soy Agar (TSA) (Merck, France), Deoxycholate (DESO) (Merck, France), and X-Gluc and Magenta-GAL (C-EC) (Compact Dry EC, Nissui pharmaceutical Co., Japan). According to their detection principles, the lethal and sub-lethal damage to $E$. coli can be assumed as shown in Table 1 (Kazama and Otaki, 2011).

Using TSA, a non-selective agar media, E. coli which can metabolize proteins (casein and soy bean) and growth, can be detected. Therefore, when the E. coli growth cannot be detected on TSA, it is assumed that its nucleic acid and/or its metabolic functions have been damaged. Using DESO (a selective agar media) selects of E. coli can grow by metabolizing lactose in the presence of deoxycholic acid. Gram-positive bacteria are unable to grow in the presence of deoxycholic acid because they lack an outer membrane and their growth is inhibited by its surface-active effects. Therefore, when E. coli cannot be detected on DESO, this indicates that its outer membrane and/or, its nucleic acid and/or its metabolic function, have been damaged. Using C-EC (a selective agar media) selects of $E$. coli can produce beta-glucuronidase (the enzyme involved in the metabolism of peptone, pyruvic acid and lactose). Therefore, when E. coli cannot be detected on C-EC, it is assumed that its enzyme activity and/or, its nucleic acid and/or its metabolic function have been damaged. By comparing the degree of inactivation on each media, the damage components and/or functions of $E$. coli could be estimated.

\section{Statistical analysis}

Values are presented as mean \pm standard deviation. Comparison test of inactivation rate constant were performed using the StatView software version 5.0 (SAS Institute Inc., Cary, NC, USA) at least significant $\mathrm{p}<0.05$ value.

\section{RESULTS \\ Injury of $E$. coli}

The degree of injury of $E$. coli during chlorine and solar disinfection was presented in Figures 1 and 2. The results showed that injured $E$. coli were detected at different levels during chlorine and solar disinfection. During chlorine disinfection, the number of injured $E$. coli increased with time and a total of $96,43 \%$ was detected after 4 hours. Similarly, during solar disinfection, the number of injured $E$. coli increased with time and a total of $71.54 \%$ was detected after 8 hours. So, the addition of chlorine and the solar exposure significantly enhanced $E$. coli inactivation causing injuries. The injury of $E$. coli should be due to the stress condition created by chlorine and solar disinfection. 
Inactivation kinetics of $E$. coli on TSA, DESO and C-EC during chlorine and solar disinfection

In this study, we have assumed that all the experiments were conducted at approximately constant concentration of disinfectant and constant UV-light intensity. Therefore, the way of quantifying the inactivation rate $\left(\mathrm{N} / \mathrm{N}_{0}\right)$ is that, the inactivation of $E$. coli followed a first order equation.

Chlorine disinfection rate has been described in the empiric model of Chick and Watson formulated as:

$$
N=N_{0} \cdot e^{-k C \cdot t}
$$

where, $\mathrm{N}$ and $\mathrm{N}_{0}$ are the concentration of $E$. coli in water at time $\mathrm{t}$ and 0 , respectively; $\mathrm{C}$ is the concentration of disinfectant, $\mathrm{k}$ is the inactivation rate constant, and $t$ is the time of exposure. In the case of the solar disinfection and in agreement with Haas (1990), we replaced the concentration of disinfectant $\mathrm{C}$ with the intensity I of insolation. The expression of the model then becomes:

$$
N=N_{0} \cdot e^{-k l \cdot t}
$$

The survival ratio of $E$. coli during chlorine and solar disinfection are presented in Figures 3 and 4 , respectively. The survival ratio of $E$. coli during chlorine disinfection showed that the inactivation was fast on TSA than both on DESO and C-EC. Nevertheless, it is slightly faster on DESO than on C-EC. These indicated that during chlorine disinfection, both viable and injured $E$. coli can easily grow on TSA than on DESO and C-EC. The survival ratio of $E$. coli during solar disinfection showed similar results for chlorine disinfection. However, the survival ratio on DESO and C-EC were slightly slow. These results showed that injured $E$. coli were able to metabolize peptone contained in TSA to ensure their growth. At the same time, they were able to metabolize sugars in DESO in the presence of deoxycholic acid, since DESO is rich in lactose. And finally, they were able to produce beta-glucuronidase, enzyme involved in the metabolism of peptone, pyruvic acid and lactose contained in C-EC. These different cultures of $E$. coli observed on TSA, DESO and C-EC, revealed various vital functions of bacterial cells during chlorine and solar disinfection.

\section{Damage mechanisms of $E$. coli}

The estimation damage of $E$. coli during chlorine and solar disinfection was evaluated by using inactivation rate constant on TSA, DESO and C-EC (Table 2). The inactivation rate constant on TSA, DESO and C-EC after chlorine and solar disinfection showed a great difference (Figures 5 and 6). After chlorine disinfection, the value on DESO $\left(0.98 \mathrm{~h}^{-1}\right)$ is higher than that on C-EC $\left(0.67 \mathrm{~h}^{-1}\right)$ and on TSA $\left(0.37 \mathrm{~h}^{-1}\right)$, but there was no significantly difference between the three values. This indicated that the main damage of E. coli was the membrane cell. The inactivation rate constant value on DESO was relatively higher than that of C-EC. This indicated that enzyme activity damage was followed by nucleic acid damage. Therefore, the inactivation of $E$. coli during chlorine disinfection is primarily and mainly due to deterioration of membrane cell, then followed by an attack of metabolic functions and finally the destruction of nucleic acid.

After solar disinfection, the inactivation rate constant on TSA $\left(0,84 \mathrm{~h}^{-1}\right)$ was higher than that on DESO $\left(0,06 \mathrm{~h}^{-1}\right)$ and on C-EC $\left(0,03 \mathrm{~h}^{-1}\right)$. This indicated that, the main cause of damage of $E$. coli was the nucleic acid. At the same time, the inactivation rate constant value on both C-EC and DESO was significantly lower than that on TSA. This indicated that the damage of the nucleic acid represents the main cause of damage occasioned by solar irradiation while the membrane and enzyme activity damage were slightly affected. Thus, the inactivation of $E$. coli during solar disinfection is due to a slight attack of the membrane and the metabolic functions then followed by an important and prior damage of the nucleic acid. 
Table 1: Assumed damages on E. coli which results in undetection for each media (Summarized by Kazama and Otaki, 2011).

\begin{tabular}{lc}
\hline Media & Damage assumed \\
\hline TSA & Nucleic acid and/or Metabolism \\
DESO & Membrane and/or Nucleic acid and/or Metabolism \\
C-EC & Enzyme activity and/or Nucleic acid and/or Metabolism \\
\hline
\end{tabular}

Table 2: Estimated damage of $E$. coli according to the detection differences among the three media.

\begin{tabular}{lllll}
\hline Media & & & & Estimated damage of $\boldsymbol{E}$. coli \\
TSA & DESO & C-EC & & \\
\hline X & X & X & $\bullet$ & Nucleic acid and/or metabolism \\
O & O & X & $\bullet$ & Enzyme activity \\
O & X & O & $\bullet$ & Membrane \\
O & X & X & $\bullet$ & Membrane and/or enzyme activity \\
\hline \multicolumn{3}{c}{ X means detected } \\
\multicolumn{3}{c}{ O means no detected }
\end{tabular}

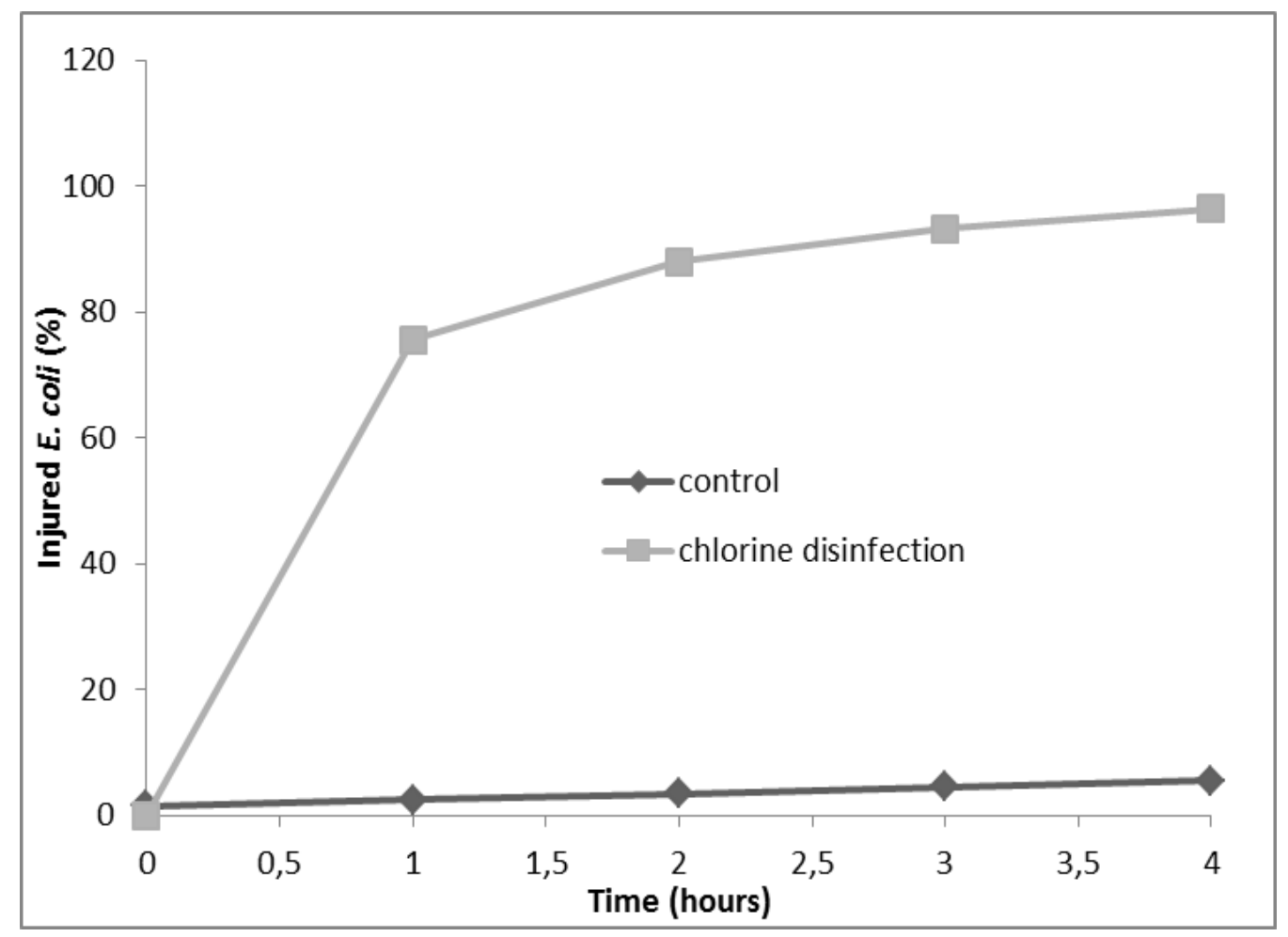

Figure 1: Injured E. coli during chlorine disinfection. 


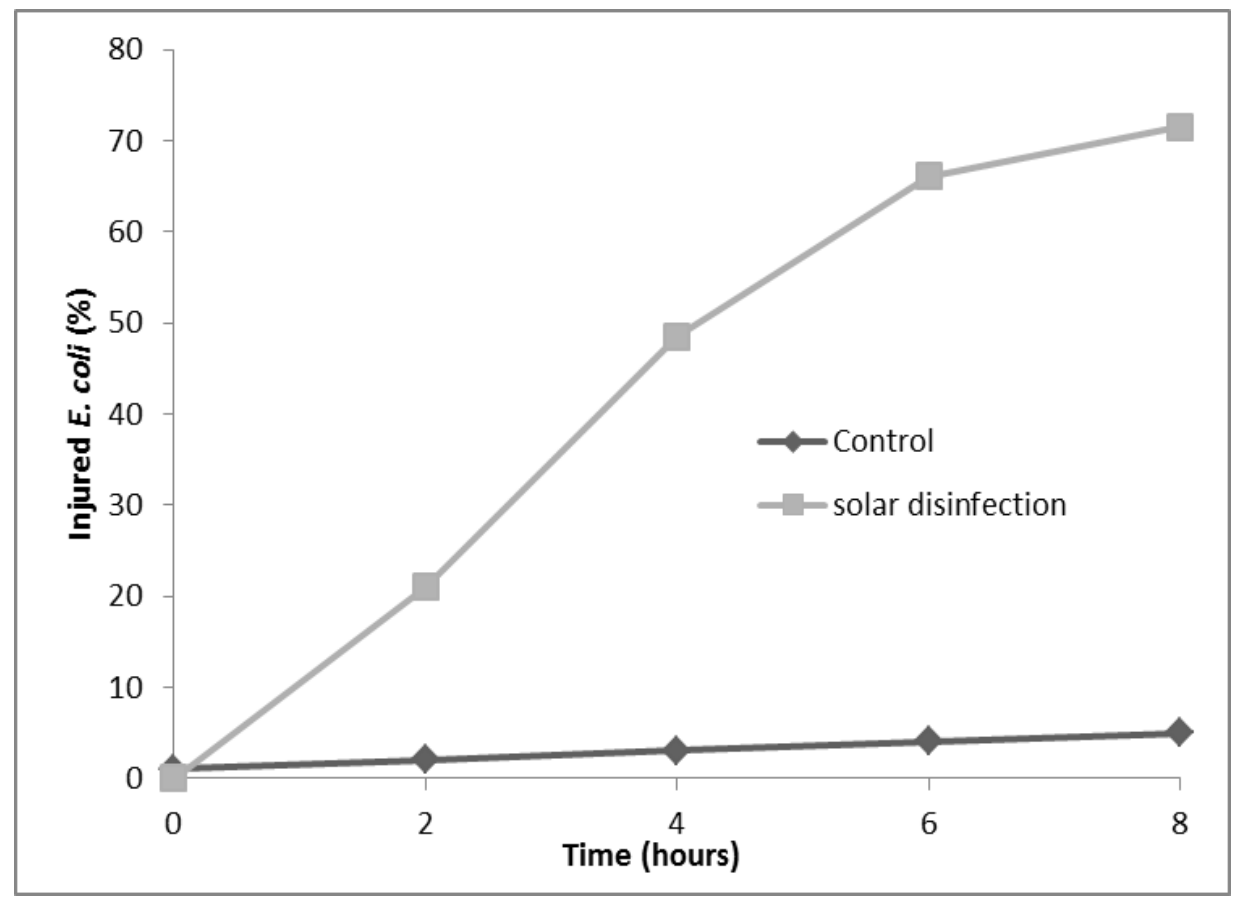

Figure 2: Injured E. coli during solar disinfection.

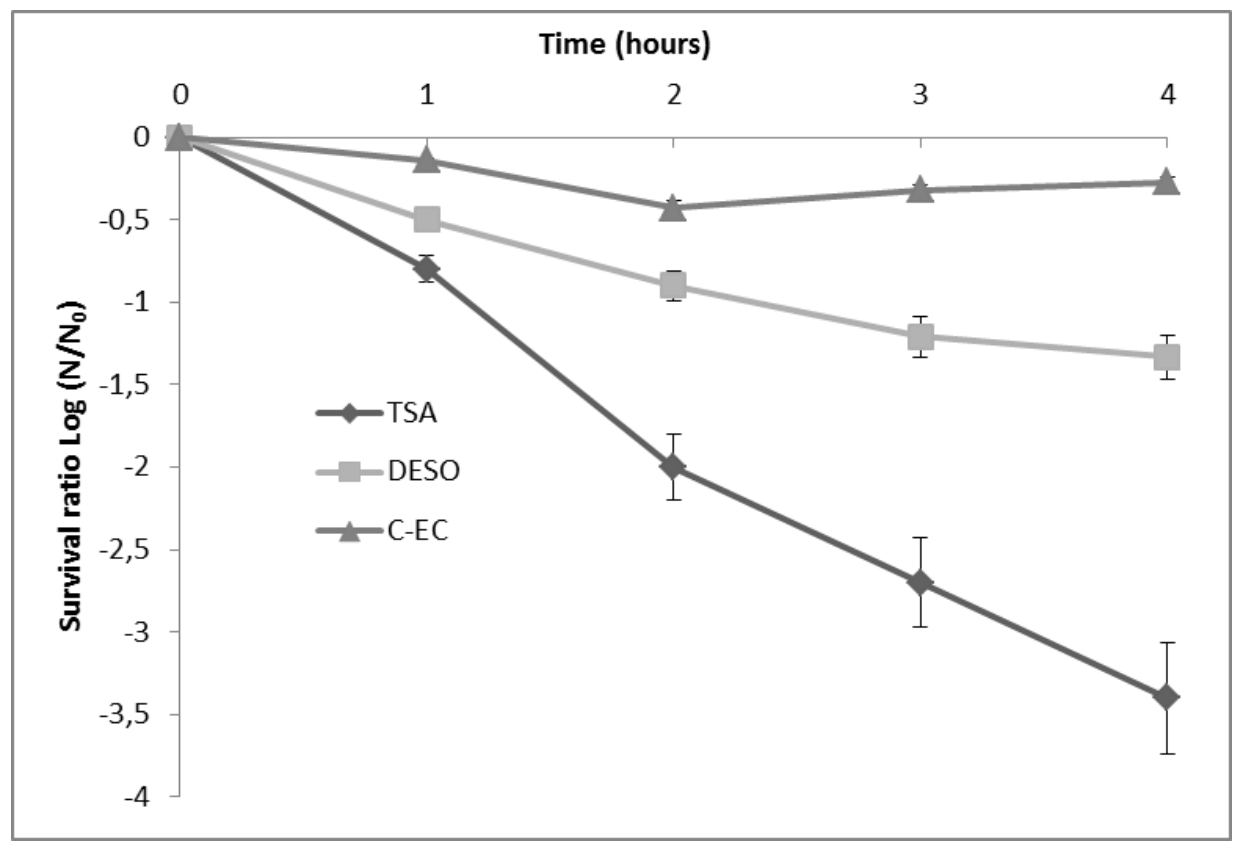

Figure 3: Survival ratio of E. coli during chlorine disinfection on TSA, DESO and C-EC. 


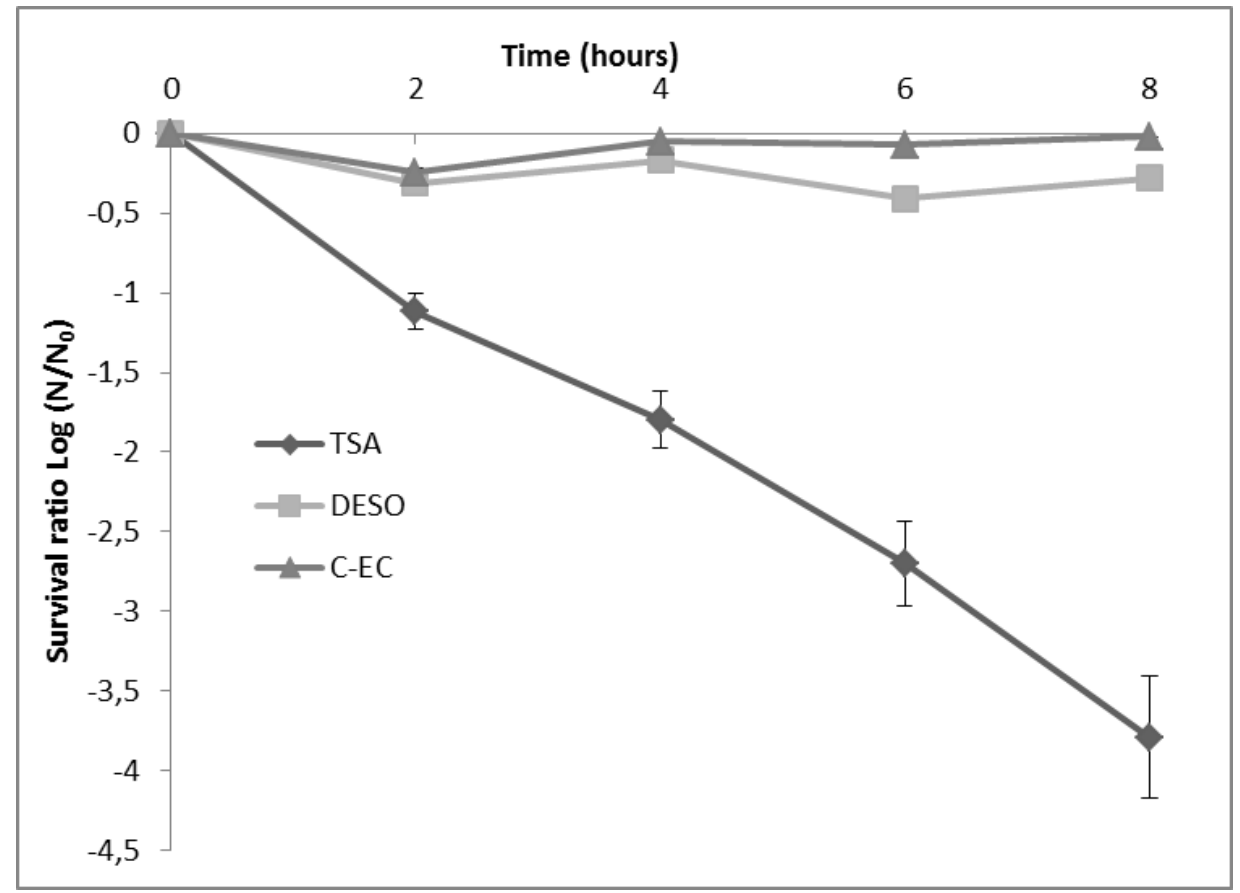

Figure 4: Survival ratio of E. coli during solar disinfection on TSA, DESO and C-EC.

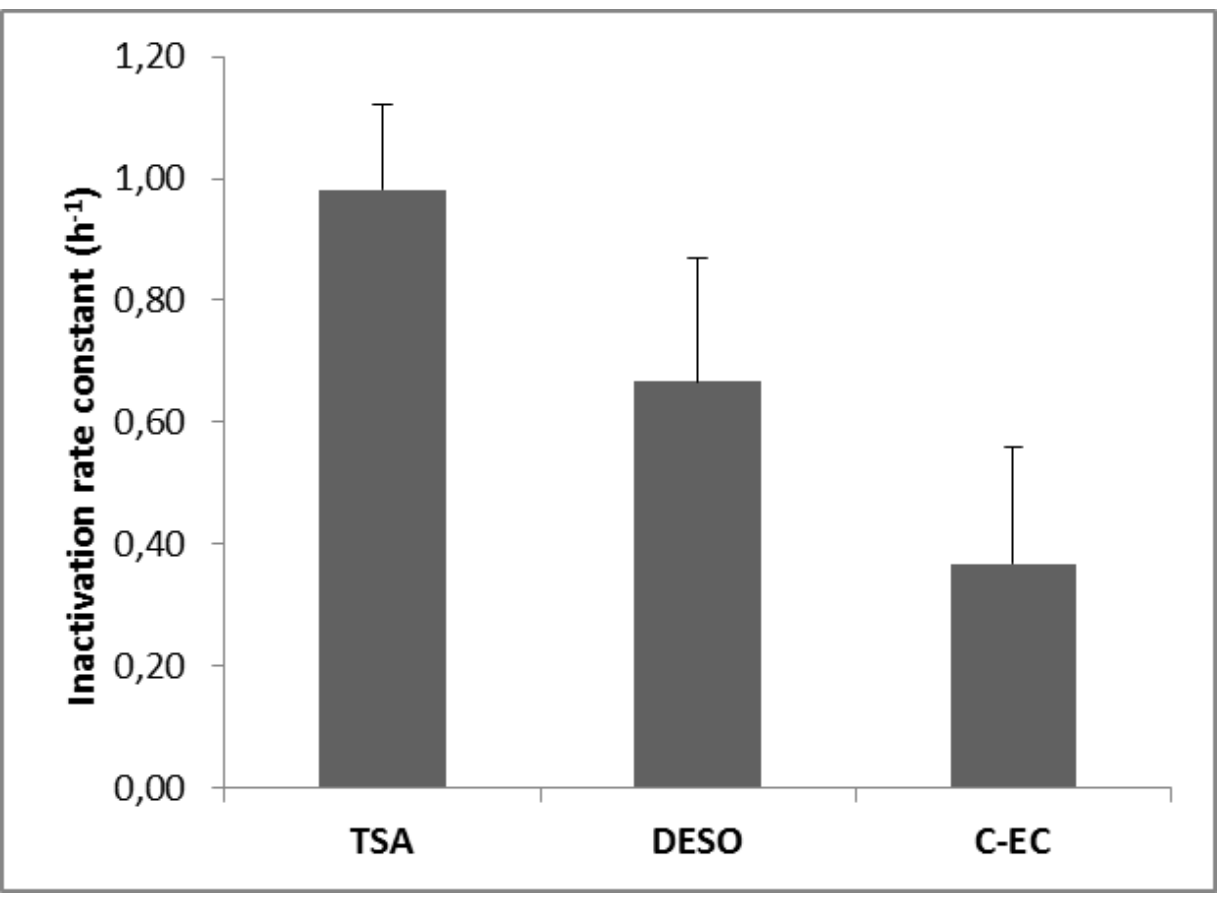

Figure 5: Estimation of damaged E. coli during chlorine disinfection. 


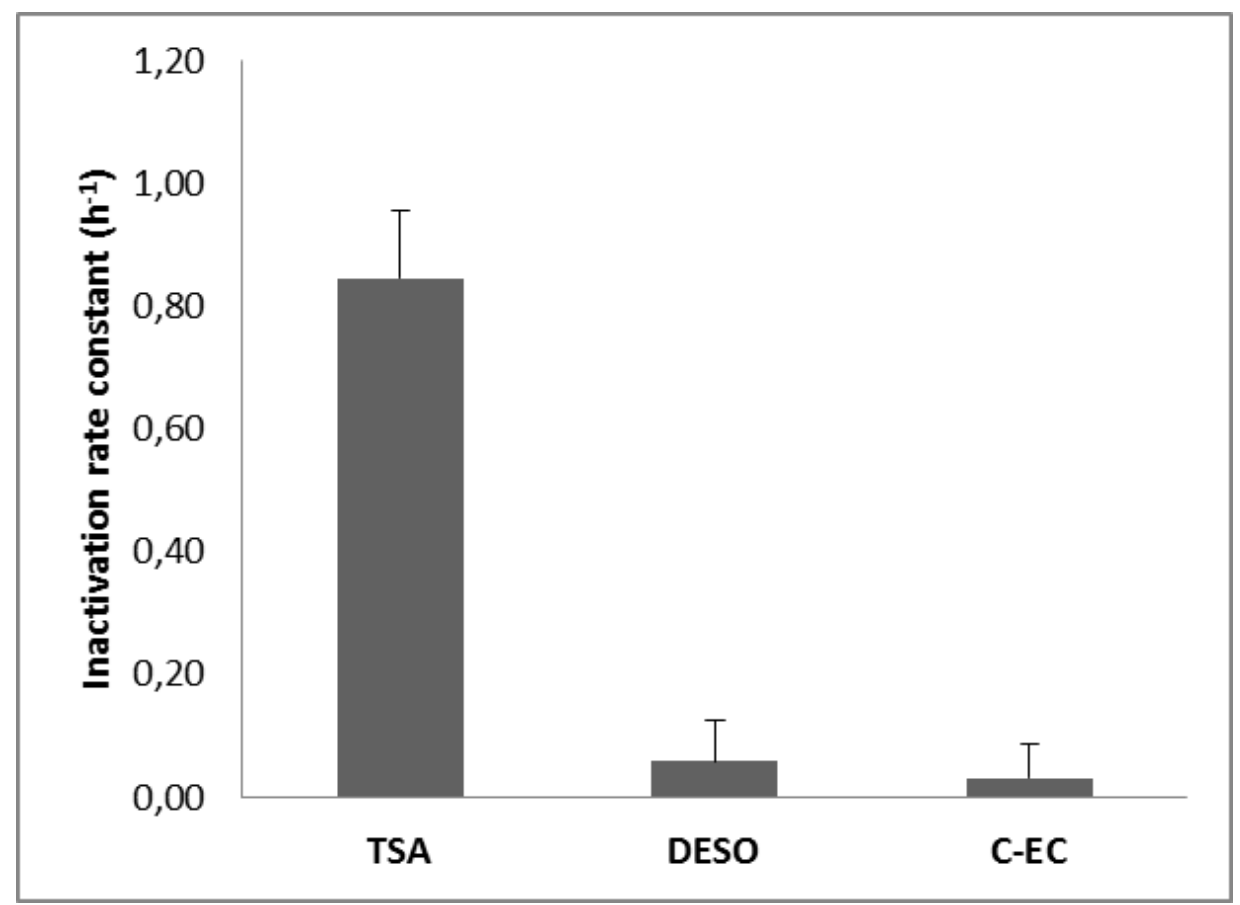

Figure 6: Estimation of damaged E. coli during solar disinfection.

\section{DISCUSSION}

The disinfection efficiency on bacteria inactivation depends on several factors such as the type of disinfectant used and the contact time with the bacteria. The addition of chlorine and solar exposure in disinfecting water enhanced significantly the inactivation of $E$. coli through injuries. The injured E. coli during chlorine and solar disinfection were detected at different levels on different culture media (selective and non-selective). This is an important characteristic of injured and noninjured E. coli. Due to their sensitivity to selective media, selective agents could affect the repair of injured cells and thereby visually unidentifiable. The comparison of bacterial colony formation on both selective and nonselective media can be used to characterize the extent of bacterial injury during disinfection (Rizzo et al., 2004; Rizzo, 2009). During cell inactivation by chlorine and solar disinfection, the surface and the intracellular of bacterial cell were attacked. Thus, many changes occurred on the protein release, lipid peroxidation, cell permeability, intracellular enzyme, nucleic acid and morphological structure levels (Cho et al., 2010). The bacterial components attacked will be lethal or sub-lethal to the bacteria depending on the mechanism of cell death.

The use of selective media during water quality control after chlorine disinfection didn't ensure the removal of E. coli. While, solar disinfection showed an effective destruction of $E$. coli. Therefore, the presence of pathogenic bacteria in water after chlorine disinfection is underestimated. According to Rizzo (2009), the compliance control for checking microbiological water quality carried out by detection of indicator microorganisms such as total coliforms as well as the selective media used for their detection is limited. Injured $E$. coli were incapable of growth through colony formation under standard conditions because of structural and metabolic damage; as a result, a significant portion of bacteria ought not be detected leading to erroneous assessment of microbial water quality (Dadie et al., 2010; Dunlop et al., 2011). In order to detect injured bacteria, less selective media must be used too (Rizzo et al., 2004), because, a non-selective agar (TSA) allows cells to repair lethal and sub-lethal damage and recover (Hijnen et al., 
2006). So, it is important to characterize the injury caused by chlorine and solar disinfection in order to check the efficiency of the process and avoid the bacteria regrowth in water.

The damage mechanisms of E. coli, showed that chlorine disinfection damages first cell membrane, then enzymatic functions and finally nucleic acid. According to Ramseier et al. (2011), during chlorine disinfection, the cell membranes were damaged by becoming permeable to staining, while the total cell concentration remained constant. This showed that bacterial membrane integrity and functionality were lost during chlorine application before the cells lost their capacity to get stained due to the DNA is heavily damaged or cell is lyse. During the chlorination, it appeared that enzymatic functions and nucleic acid were also damaged. Ramseier et al. (2011) found in chlorination experiments with E. coli that other cellular functions ceased before the membrane integrity was lost. Chlorine is the strongest oxidant among chemical disinfectants and partition into and penetration through cell's protective barrier are accompanied by reaction with various cell wall components as evidenced by the significant level of enzyme activity damage. Until these reactions are sufficiently completed, penetration into the cell plasma and direct reaction with intracellular components are limited. So, the cell death by chlorine is related to nucleic acid and enzyme activity damage but primarily and firstly related to cell membrane damage. Experimental results suggested that bacteria inactivation by chemical disinfectants showed a consistent pattern, with the greatest level of membrane damage by free chlorine (Cho et al., 2010). Therefore, different mechanisms involved in chlorine disinfection depend on the type of chlorine-based disinfectants.

The inactivation of $E$. coli during solar disinfection was mainly due to nucleic acid damage. Douki et al. (2003) reported that the oxidative damage of DNA is the main inducing damage that occurs by the UV irradiation which constitutes the largest part of solar irradiation. During solar disinfection, it is well known that UV lights specifically induce direct photochemical damage to intracellular DNA nucleic acid (Sinha and Häder, 2002). At the same time, the inactivation of $E$. coli showed little or no membrane damage and enzyme activity. Therefore, during solar UV disinfection, the UV irradiation tackled in priority nucleic acid preceded by a slight attack of membrane and enzyme activity. Nocker et al. (2007) reported that DNA nucleic acid of $E$. coli was extensively damaged by UV lights while the membrane was still impermeable to staining. In contrast, sufficient exposure of $E$. coli to UV-A damaged bacterial membrane proteins (Berney et al., 2008) but not the outer cell membrane. Ramseier et al. (2011) demonstrated that one of the basic differences between chemical disinfection and inactivation by UV lights is that UV inactivation is based on absorption of the irradiation by bacterial DNA, followed by the formation of thymine dimmers.

Understanding the damage mechanisms of bacteria inactivation using water disinfectants makes it critical to identify the rate-limiting steps involved in the inactivation process. Therefore, in order to provide an explanation on the presence or absence of synergism in sequential application of these disinfectants it is important to develop more effective disinfection strategies. Synergism in the sequential disinfection scheme is defined as enhanced disinfection kinetics during the secondary disinfection due to primary disinfectant application. For example, application of solar disinfection followed by free chlorine could be interesting. Solar disinfection can damage primary acid nucleic and chlorination will damage cell membrane and enzymes functions.

During the experiment, the damage mechanisms were deduced from growth or lack of growth on specific media but the mode of action of chlorine and solar UV had actually not been studied at the genetic and epigenetic level. So, other damage 
mechanisms not elucidated in this study could occur. Alternatively, during chlorination the cell death could be induced without involving damage in surface structure. In such case, direct impairment in intracellular functions would be the primary reason for cell death and growth inhibition. Chemical disinfectants might also attack directly intracellular components without involving significant surface disruption. For example, Cho et al. (2010) proposed a protein synthesis disruption as the primary mechanism of $E$. coli death under chlorine dioxide treatment. Gray et al. (2012) observed damage of cell respiratory system and DNA when vegetative microorganisms were inactivated by free chlorine. Shang and Blatchley (2001) reported that combined chlorine would readily react with some amino acids of the bacteria. In the case of solar disinfection, Blokhina et al. (2003) investigated the UVA damage of $E$. coli under different environmental conditions and concluded that UVA exposure can alter the membrane structure of the bacteria by oxidative mechanisms. Cho et al. (2010) reported that bacteria have developed several complex mechanisms, with a considerable degree of overlap, to allow them to cope with potential oxidative hazards. Several genes belonging to different regulatory systems are known to be involved in the defense against oxidative stress of bacteria (Lushchak, 2011).

In this study, only E. coli as a model of pathogenic bacteria for damage estimation was evaluated. Other pathogens, such as Salmonella, those in form of cocci or spore ought to be less affected by inactivation in drinking water disinfection. Therefore, inactivation of those more resistant pathogens had to be considered. On the other hand, the plating method used in this study for damage mechanisms was limited because that could not show the resistance of bacteria which were decisively determined with cell wall permeability against specific disinfectant. However, it should be reminded that the elimination of bacteria in drinking water is not synonymous of water quality, other tests and other treatments were necessary for the damage mechanisms of pathogenic bacteria to ensure a quality drinking water after disinfection. .

\section{Conclusion}

This study aimed at elucidating the inactivation mechanisms of pathogenic bacteria in drinking water during chlorine and solar disinfection using a simple plating method. The results showed that, injured $E$. coli were detected at different levels during chlorine and solar disinfection. The use of selective media during water quality control showed effectively a destruction of $E$. coli during solar disinfection while, the removal of E. coli during chlorine disinfection was not ensure. The damage of cell components and/or metabolic functions showed that there is a primary and main damage of E. coli during chorine and solar disinfection. Chlorination damaged firstly and mainly the membrane cell followed by enzymatic functions and nucleic acid; while solar disinfection damaged mainly the nucleic acid. The use of simple plating method in water quality control is limited by the choice of plating media depending on the disinfectant used. The understanding of damage mechanisms of pathogenic bacteria cells during disinfection helps improve drinking water quality control and develops more effective disinfection strategies.

\section{COMPETING INTERESTS}

The authors declare that there is no conflict of interest. The project was selffunded by the authors.

\section{AUTHORS' CONTRIBUTIONS}

The authors SKS, DKG, YK and BS contributed to all the steps leading to this manuscript: study preparation, data collection, data analysis, manuscript design and preparation, manuscript writing. YA, AHM and NF contributed to the supervision of the work, guidance, expert advice and manuscript design and correction. 


\section{ACKNOWLEDGEMENTS}

The authors wish to express their sincere thanks to the staff of the Laboratory of Water, Sanitation, Ecosystem and Health (LEDES), for the technical assistance rendered during the course of work.

\section{REFERENCES}

Al-Adhami BH, Nichols RAB, Kusel JR, O'Grady J, Smith HV. 2007. Detection of UV-induced thymine dimers in individual Cryptosporidium parvum and Cryptosporidium hominis oocysts by immunofluorescence microscopy. Applied and Environmental Microbiology, 73: 947-955. http://dx.doi.org/10.1128/AEM.01251-06

Berney M, Vital M, Hülshoff I, Weilenmann HU, Egli T, Hammes F. 2008. Rapid, cultivation-independent assessment of microbial viability in drinking water. Water Research, 42: 4010-4018. http://dx.doi.org/10.1016/j.watres.2008.0 7.017

Blokhina O, Virolainen E, Fagerstedt KV. 2003. Antioxidants, oxidative damage and oxygen deprivation stress: a review. Annals of Botany, 91(2): 179-194. http://dx.doi.org/10.1093/aob/mcf118

Cabral JP. 2010. Water microbiology. Bacterial pathogens and water. International Journal of Environmental Research and Public Health, 7(10): 3657-3703. http://dx.doi.org/10.3390/ijerph7103657

Cho M, Kim J, Kim JY, Yoon J, Kim JH. 2010. Mechanisms of Escherichia coli inactivation by several disinfectants. Water Research, 44: 3410-3418. http://dx.doi.org/10.1016/j.watres.2010.0 3.017

Dadie A, Dje M, Brou K, Dosso M. 2010. Performance of selective media for E. coli O157, using non-sorbitol fermenting strains and physiological characters of shiga-toxin producing species isolated in Côte d'Ivoire. International Journal of Biological and Chemical Sciences, 4(1). http://dx.doi.org/10.4314/ijbcs.v4i1.54230
Douki T, Reynaud-Angelin A, Cadet J, Sage E. 2003. Bipyrimidine photoproducts rather than oxidative lesions are the main type of DNA damage involved in the genotoxic effect of solar UVA radiation. Biochemistry, $\quad$ 42(30): $\quad$ 9221-9226. http://dx.doi.org/10.1021/bi034593c

Dunlop PSM, Ciavola M, Rizzo L, Byrne JA. 2011. Inactivation and injury assessment of Escherichia coli during solar and photocatalytic disinfection in LDPE bags. Chemosphere, 85(7): 1160-1166. http://dx.doi.org/10.1016/j.chemosphere.2 011.09.006

Escheid AC, Meyer JN, Linden KG. 2009. UV disinfection of adenoviruses: molecular indications of DNA damage efficiency. Applied and Environmental Microbiology, 75: 23-28. http://dx.doi.org/10.1128/AEM.02199-08

Giannakis S, Darakas E, Escalas-Cañellas A, Pulgarin C. 2014. Elucidating bacterial regrowth: Effect of disinfection conditions in dark storage of solar treated secondary effluent. Journal of Photochemistry and Photobiology A: Chemistry, 290: 43-53. http://dx.doi.org/10.1016/j.jphotochem.201 4.05.016

Gray MJ, Wholey WY, Jakob U. 2012. Bacterial responses to reactive chlorine species. Annual Review of Microbiology, 67: 141-160. http://dx.doi.org/ 10.1146/annurev-micro-102912-142520

Haas CN. 1990. Disinfection. Water Quality and Treatment. In: A Handbook of Community Water Supplies. American Water Works Association. (FW Pontius, edition).

Hijnen WAM, Beerendonk EF, Medema GJ. 2006. Inactivation credit of UV radiation for viruses, bacteria and protozoan oocysts in water: a review. Water Research, 40: 322. http://dx.doi.org/10.1016/j.watres. 2005.10.030

Hrudey SE, Charrois JW. 2012. Disinfection By-Products: Relevance to Human Health. IWA Publishing.

Jungfer C, Schwartz T, Obst U. 2007. UVinduced dark repair mechanisms in 
bacteria associated with drinking water. Water Research, 41: 188-196. http://dx.doi.org/10.1016/j.watres.2006.0 9.001

Kazama S, Otaki M. 2011. Mechanisms for the inactivation of bacteria and viruses in sawdust used in composting toilet. Journal of Water and Environment Technology, 9: 53-66. http://dx.doi.org/10.2965/jwet.2011.53

Lushchak VI. 2011. Adaptive response to oxidative stress: Bacteria, fungi, plants and animals. Comparative Biochemistry and Physiology Part C: Toxicology \& Pharmacology, 153(2): 175-190. http://dx.doi.org/10.1016/j.cbpc.2010.10. 004

McFeters GA, Kippin JS, LeChevallier MW. 1986. Injured coliforms in drinking water. Applied and Environmental Microbiology, 51: 1-5. PMCID: PMC238806

McGuigan KG, Conroy RM, Mosler HJ, du Preez M, Ubomba-Jaswa E, FernandezIbañez P. 2012. Solar water disinfection (SODIS): A review from bench-top to roof-top. Journal of Hazardous Materials, 235: 29-46. http://dx.doi.org/10.1016/j.jhazmat.2012. 07.053

Nocker A, Sossa KE, Camper AK. 2007. Molecular monitoring of disinfection efficacy using propidium monoazide in combination with quantitative PCR. Journal of Microbiological Methods, 70: 252-260.

http://dx.doi.org/10.1016/j.mimet.2007.04 .014

Orjiekwe CL, Dumo DT, Chinedu NB. 2014. Assessment of water quality of Ogbese River in Ovia North-East Local Government Area of Edo State, Nigeria. International Journal of Biological and Chemical Sciences, 7(6): 2581-2590. http://dx.doi.org/10.4314/ijbcs.v7i6.32

Ramseier MK, von Gunten U, Freihofer P, Hammes F. 2011. Kinetics of membrane damage to high (HNA) and low (LNA) nucleic acid bacterial clusters in drinking water by ozone, chlorine, chlorine dioxide, monochloramine, ferrate (VI), and permanganate. Water Research, 45: 1490-1500. http://dx.doi.org/10.1016/ j.watres.2010.11.016

Richardson SD, Postigo C. 2012. Drinking water disinfection by-products. Emerging Organic Contaminants and Human Health, 20: 93-137. http://dx.doi.org/10.1007/698_2011_125

Rizzo L, Belgiorno V, Napoli RMA. 2004. Regrowth evaluation of coliform bacteria injured by low chlorine doses using selective and non-selective media. Journal of Environmental Science and Health. Part A, Toxic/hazardous Substances \& Environmental Engineering, 39: 20812092. http://dx.doi.org/10.1081/ESE120039376

Rizzo L. 2009. Inactivation and injury of total coliform bacteria after primary disinfection of drinking water by $\mathrm{TiO}_{2}$ photocatalysis. Journal of Hazardous Materials, 165: 4851. http://dx.doi.org/10.1016/j.jhazmat. 2008.09.068

Shah AD, Krasner SW, Lee CFT, von Gunten U, Mitch WA. 2012. Trade-offs in disinfection byproduct formation associated with precursor preoxidation for control of N-nitrosodimethylamine formation. Environmental Science and Technology, 46(9): 4809-4818. http://dx.doi.org/10.1021/es204717j

Shang C, Blatchley ER. 2001. Chlorination of pure bacterial cultures in aqueous solution. Water Research, 35(1): 244254. http://dx.doi.org/10.1016/S00431354(00)00248-7

Shin GA, Linden KG, Arrowood MJ, Sobsey MD. 2001. Low pressure UV inactivation and DNA repair potential of Cryptosporidium parvum oocysts. Applied and Environmental Microbiology, 67: 3029-3032. http://dx.doi.org/10.1128/AEM.67.7.3029 $-3032.2001$

Sinha RP, Häder DP. 2002. UV-induced DNA damage and repair: a review. Photochemical \& Photobiological 
Sciences, $\quad$ 1(4): 225-236. http://dx.doi.org/10.1039/B201230H

Wahome CN, Okemo PO, Nyamache AK. 2014. Microbial quality and antibiotic resistant bacterial pathogens isolated from groundwater used by residents of Ongata Rongai, Kajiado North County, Kenya. International Journal of Biological and Chemical Sciences, 8(1): 134-143. http://dx.doi.org/10.4314/ijbcs.v8i1.13

WHO, UNICEF. 2014. Progress on Sanitation and Drinking-Water. 2014 update. WHO Press:

Geneva, Switzerland.www.wssinfo.org

Xue C, Wang Q, Chu W, Templeton MR. 2014. The impact of changes in source water quality on trihalomethane and haloacetonitrile formation in chlorinated drinking water. Chemosphere, 117: 251$255 . \quad$ http://dx.doi.org/10.1016/j. chemosphere.2014.06.083

Zogo D, Bawa LM, Soclo HH, DjanéyéBoundjou G, Atchekpe D. 2010. Effect of pre-chlorination on the efficiency of iron and manganese removal from surface water by coagulation-flocculation using aluminium sulphate: case of the Okpara dam in the Republic of Benin. International Journal of Biological and Chemical Sciences, 4(6). http://dx.doi.org/10.4314/ijbcs.v4i6.64983 